CONTEMPORARY

CHALENGES

IN SUPPLY CHAINS VOL. 1

Adam Koliński, Jerzy Kur, Szymon Strojny, Danuta Głowacka-Fertsch (Eds.)

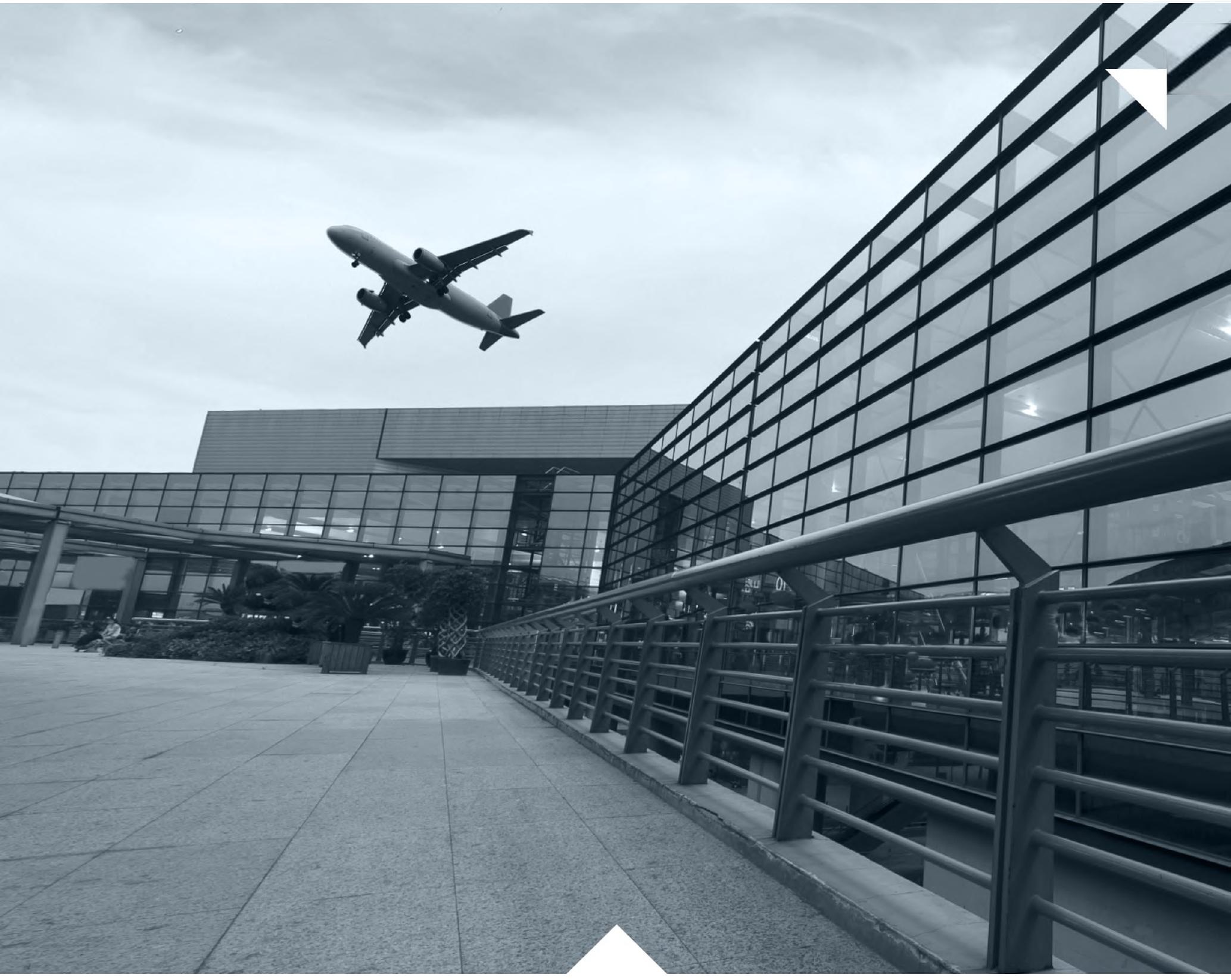



Adam Koliński

Jerzy Kur

Szymon Strojny

Danuta Głowacka-Fertsch

\section{CONTEMPORARY}

\section{CHALLENGES IN SUPPLY CHAINS}

Radom 
Recenzenci:

dr hab. inż. Piotr Cyplik - Wyższa Szkoła Logistyki Poznań

dr inż. Michał Adamczak - Wyższa Szkoła Logistyki Poznań

Afiliacja naukowa: Wyższa Szkoła Logistyki z siedzibą w Poznaniu

Projekt okladki: JUST Agencja Reklamowa

Opracowanie redakcyjne: Adam Kolinski

Redakcja techniczna: Kamila Janiszewska

(C) Copyright by Authors

(C) Copyright by Instytut Naukowo-Wydawniczy „Spatium”, Radom 2019

e-ISBN 978-83-66017-88-7

Wydano nakladem:

Instytutu Naukowo-Wydawniczego „Spatium”

26-600 Radom, ul. 25 Czerwca 68

tel. 483698074 , fax 483698075

e-mail: wydawnictwo@inw-spatium.pl

http://www.inw-spatium.pl 


\section{CONTENT}

Preface. $\mathrm{V}$

I.GENERAL CHALLENGES IN SUPPLY CHAINS . 1

Anna Tatarczak, Grzegorz Grela

PRACTICAL EXAMPLES OF HORIZONTAL COLLABORATION IN LOGISTICS: A

LITERATURE REVIEW

Rafal Matwiejczuk

THE DEVELOPMENT OF BUSINESS LOGISTICS CONCEPT. FROM OPERATIONAL MANAGEMENT OF LOGISTICS PROCESSES TO THE INTEGRATED FLOW MANAGEMENT WITHIN THE SUPPLY NETWORK

Mariusz Szuster

GEOPOLITICAL DIMENSION OF BUILDING THE NEW SILK ROAD ..................... 25

II. IMPACT OF CUSTOMER RELATIONS ON LOGISTICS OPTIMIZATIONS ..... 42

Halina Szulce

IMPORTANCE AND OPPORTUNITIES OF BUILDING CUSTOMER RELATIONS ON

THE B2B MARKET.

Szymon Strojny

LOGISTICS ASPECTS OF CREATING TOUCHPOINTS IN THE CUSTOMER SERVICE PROCESS.

Maciej Bieńczak, Marek Piosik Hanna Sawicka, Piotr Sawicki, Waldemar

Walerjańczyk, Paweł Żmuda-Trzebiatowski

BEHAVIOR OF CUSTOMERS USING CEP INFRASTRUCTURE

Andrzej Rzeczycki

BAHAVIOURAL ASPECTS OF DECISION MAKING IN LOGISTICS.

III. LOGISTICS CHALLENGES AT OPERATIONAL LEVEL 93

Anatoliy Pilyavskyy, Anna Maryniak, Yuliia Bulhakova

KEY SUCCESS FACTORS IN MANAGING SUPPLY CHAIN - ISM ANALYSIS 94

\section{Magdalena Malinowska}

THE APPLICATION OF FUZZY SETS TO DETERMINE THE CRITERIA OF THE SUSTAINABLE WAREHOUSING ASSESSMENT MODEL 106

\section{Mariusz Sowa}

IDENTIFICATION OF ENDO- AND EXOGENOUS FACTORS INFLUENCING

INDIVIDUAL DURATION TIME OF THE OPERATING PHASE OF A FLAT

PALLET 
CONTEMPORARY CHALLENGES IN SUPPLY CHAINS VOL. 1

Magdalena Satora, Teresa Gajewska, Maciej Szkoda

ANALYSIS OF SELECTED FACTORS INFLUENCING THE IRREGULARITY OF DELIVERIES OF FRUIT AND VEGETABLES. 


\section{Preface}

The main topic of this monograph is the contemporary challenges analysis in supply chains. This issue is topical from both a scientific and a business practice point of view. Due to the complexity of the subject matter and an attempt to systematize it, it was decided to separate three basic ranges for this monograph.

Part 1 discusses the logistics challenges at the supply chain management level. The logistics industry is highly competitive, so in order to increase efficiency, competing companies may establish a collaboration. Collaborative logistics is an active research area of practical importance and it also presents interesting research opportunities.

A separate issue is the integration of information flow in supply networks. Firms constantly search for ways enabling them to achieve and maintain long-term competitive advantage. Among the most significant concepts influencing the achievement of such an advantage by a firm, an important role is played by the business logistics concept.

A very important issue in terms of supply chain management is planning and organising the new silk road. For many countries, this project is an opportunity for development. The logistics industry should also benefit.

In the second part, an analysis was made of the customer relationship impact on logistics optimisation. A very important aspect are opportunities of building customer relations on the B2B market. One of the most important elements of the relational strategy is to get to know the customer, which requires time and cost-intensive expenditures. It also requires changes in the organization of the company and a specific approach to the recruitment of employees who carry out relational activities and try to determine the current and future needs of customers.

Logistics aspects of creating touchpoints in the customer service process is another element worthy of deeper analysis. The development of new forms of omni-channel sales affects changes in customer purchasing processes, therefore a customer-oriented company must take these changes into account in its customer service strategy.

A specific aspect of customer relations is Courier, Express and Parcel (CEP) industry. One of important elements of a logistics infrastructure in the CEP industry is a Pick-up and Drop-off Point, referred to PUDO. This is the point of relation between a customer and an operator. A dynamic evolution of e-commerce translates directly into the development of this type of infrastructure elements.

Customer relations also influence the decision-making process. Managers goals may differ from the company's and the supply chain objectives. Theirs values and goals can lead to subjective-rational behaviours, which from the point of view of the organization will be 
irrational. Subrational behaviours may also result from motivational problems leading to the lack of commitment in new ventures, not taking opportunities, postponing tasks for later and transferring them to others.

The 3 part of the monograph presents logistics challenges at the operational level. The identification of key success factors in managing supply chain (SCM) is one of the main tasks of managers, but still a weakly explored study field. In this regard, there is lack a comprehensive approach, in which financial, infrastructure, logistic, administrative and relational aspects are simultaneously examined.

One of the modern trends is the orientation towards sustainable warehousing processes. Such approach is complied with context of sustainable warehousing in which the warehouse is a unit equipped by appropriate technological and organizational solutions allowing to operate maintaining the high standards of work, reduce the negative impact on the environment and achieve the lover cost of its functioning.

A pallet is a supporting transport and storage equipment, adapted to motorized facilities and for stacking loads. Pallet load units created on the basis of various types of pallets can be used in rotation taking place in numerous actors of chains of supply. To be considered safe in the operating phase each pallet, regardless of its type, has to meet particular formal requirements as early as at the workmanship phase.

The last issue raised is the specificity of the supply of vegetables and fruit. The seasonal nature of the supply of fresh fruit and vegetables is a real challenge for companies that deal with their delivery. In the case of enterprises whose activity is focused primarily on the international transport of this type of products, the key is to look for new producers or expand their activities to the domestic country, in order to limit the impact of seasonality on the number of deliveries. Logistics challenges are an initial phase of modern trends in supply chains, but the subject matter contained in this monograph does not cover the entire spectrum.

We encourage you to read and contact the authors of individual chapters. One of the goals of the monograph is to present the results of the authors' work, which will enable establishing cooperation, building new scientific teams and conducting research relevant to the development of the logistics field.

Adam Koliński, Jerzy Kur, Szymon Strojny, Danuta Głowacka-Fertsch

Editors 


\section{LOGISTICS CHALLENGES AT SUPPLY CHAIN MANAGEMENT LEVEL}


Anna Tatarczak

Uniwersytet im. Marii Curie-Skłodowskiej Lublin

e-mail: anna.tarczak@poczta.umcs.lublin.pl

Grzegorz Grela

Uniwersytet im. Marii Curie-Skłodowskiej Lublin

e-mail: grzegorz.grela@umcs.lublin.pl

\title{
PRACTICAL EXAMPLES OF HORIZONTAL COLLABORATION IN LOGISTICS: A LITERATURE REVIEW
}

\begin{abstract}
Background: The logistics industry is highly competitive, so in order to increase efficiency, competing companies may establish a collaboration. Existing studies in both the professional and academic literature concerning horizontal logistics cooperation emphasize the demonstration of potential cost savings and the reduction of $\mathrm{CO}_{2}$ emissions through cooperation. The aim of this chapter is to provide a structured and representative review of horizontal cooperation at a practical level

Methods: The first stage of our research consisted of a systematic review of electronic bibliographic databases, most of them were published between 2010 and 2018. In the second stage, a selection of articles was chosen from among the results of the search. The selection was aimed at identifying articles with real-data cases and includes well-known problems such as the traveling salesman and vehicle routing. The literature concerning logistics cooperation was also examined to describe the main cost allocation methods that are based on practical requirements. Results: For each business collaboration scenario the potential benefits of horizontal collaboration between firms are confirmed and profit maximization is particularly emphasized when compared with a typical standalone situation. The chapter shows that despite the increasing number of publications concerning the subject, several areas of research are still being neglected. The contribution of our survey is twofold. Firstly, we survey the literature of the last few years. Secondly, the drivers, impediments, and facilitations of horizontal cooperation are reviewed.
\end{abstract}

Conclusions: Collaborative logistics is an active research area of practical importance and it also presents interesting research opportunities. Moreover, some interesting directions for 
future research have been identified, an example of which is the investigation of effective profit and cost-sharing mechanisms being applied to more complex transportation systems.

Keywords: collaborative logistics, horizontal collaboration, transportation, supply chain

\section{INTRODUCTION}

The objective of the article, as stated by the authors, is to present the conclusions of the analysis and the practical examples of horizontal collaboration in logistics described in the literature. One of the more general definitions of horizontal cooperation is the one proposed by the European Commission, according to which "a cooperation is of a "horizontal nature" if an agreement or concerted practice is entered into between companies operating at the same level(s) in the market. In most instances, horizontal cooperation amounts to cooperation between competitors." [European Commission 2001]. Within the context of this article, we have adopted the definition proposed by Juan et al. (2014) i.e. "horizontal cooperation in logistics refers to how two or more companies can cooperate in order to achieve a common objective, which is usually related to the minimization of global distribution costs." [Juan et al. 2014]. Unlike vertical cooperation, where the cooperation concerns suppliers and buyers, which is natural, horizontal cooperation involves the cooperation of competitors, which is not obvious. This phenomenon is easier to understand if we look at horizontal cooperation in logistics as a non-zero-sum game, where the profit of one company does not equate to a loss for the other, even though they compete in the same market. In this case, initiating cooperation may imply a win-win result.

The aim of the analysis of the collected articles concerning horizontal cooperation in logistics was to determine a common objective of cooperation by identifying the type of problem solved by horizontal cooperation, the adopted solution methodology and benefits of collaboration.

The following research questions were formulated:

Q1: What are the problems solved by horizontal cooperation in logistics?

Q2: What are the methodologies of the adopted solutions?

Q3: What are the main benefits of horizontal cooperation in the analysed articles? 


\section{RESEARCH METHODOLOGY}

This section describes how the review was performed for this paper. A literature review of both academic research and practical papers concerning horizontal cooperation in logistics was conducted using the systematic literature review method.

In order to identify the relevant literature, a two-step approach was used. Firstly, the relevant literature was gathered using electronic bibliographical databases such as Scopus, Web of Science and Google Scholar. With regard to the decision framework, initial search terms included 'horizontal cooperation', 'horizontal collaboration', 'coalition', 'alliance', and 'horizontal alliance' combined with the terms 'logistics', 'formation' and 'decision process'. In addition, these keywords and terms were combined for further searches using the Boolean operators AND and OR. Through the use of this method, we identified the first set of relevant studies. In total, 127 articles published in journals were discovered.

The second step involved the careful selection of each article. The scope of the research and the focus area were decided upon after the initial screening process. Next, in order to identify the number of potential papers directly related to horizontal cooperation in logistics, the 82 abstracts were selected based on their keywords and content and deemed suitable for inclusion in the systematic literature review. The majority of these abstract were from logistics and supply chain management journals. In Table 2. we provide an overview of journals, in which at least two relevant articles were published.

Table 2. Number of articles published by journal.

\begin{tabular}{lc}
\hline \multicolumn{1}{c}{ Journal } & Number of articles \\
\hline European Journal of Operational Research & 5 \\
CIRP Journal of Manufacturing Science and Technology & 2 \\
Decision Support Systems & 2 \\
Mathematical Problems in Engineering & 2 \\
OR spectrum & 2 \\
Production Planning \& Control & 2 \\
Transportation Science & 2
\end{tabular}




\section{COLLABORATION IN LOGISTICS}

\subsection{Problem classification}

In both academic and professional literature the various types of cooperation in horizontal logistics have been discussed. There are several ways in which horizontal cooperation in logistics may occur: carriers may collaborate with each other, shippers may also collaborate by joining these collaborative groups, and finally, shippers may collaborate among themselves. The first problem (transportation planning) concerns the problem that a certain product is available in limited quantities at several locations and must be transported to destinations at a minimum total cost such that the demand quantities at the destinations are satisfied and the supply availability at the original locations is not exceeded [Guajardo and Ronnqvist 2015]. The vehicle routing problems (VRP) in horizontal coalitions of freight carriers have attracted the interest of several researchers in the last few years, moreover thousands of companies are confronted by this problem on a daily basis. Through the presentation of different categories of VRP in transportation logistics and distribution systems, many researchers have studied the algorithms and models for different versions of VRP. There are three main research streams: centralized collaborative planning, decentralized planning without auctions, and auction-based decentralized planning [Ganstere and Hartl 2018].

The cooperation in sales problem is defined through the joint planning of routes with the objective of minimizing the total traveling costs of a coalition, the tour starts at the origin, visits each point just once and finishes at the origin. This problem is closely related to the multi-depot vehicle routing problem. However, there aren't capacity restrictions.

The fourth category of problem analysed is the collaborative logistics joint distribution problem, which can effectively reduce the crisscross transportation phenomenon and improve the efficiency of the urban freight transportation system [Wang et al. 2017].

The last class of problems is the inventory routing problem that addresses the coordination of inventory management and vehicle routing in a supply chain [Jemai et al. 2013].

Table 2. Problem classification and references

\begin{tabular}{|c|c|c|}
\hline Problem & References & Area of application \\
\hline \multirow{2}{*}{ 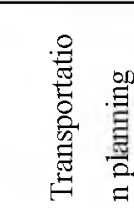 } & Guajardo and Ronnqvist 2015 & $\begin{array}{l}\text { Collaborative forest transportation and the inventory of spare parts } \\
\text { for oil operations is considered. }\end{array}$ \\
\hline & Wang et al. 2015 & $\begin{array}{l}\text { The chapter presents the problem of vehicle route scheduling and } \\
\text { profit allocation for multiple distribution centres. A model to }\end{array}$ \\
\hline
\end{tabular}


CONTEMPORARY CHALLENGES IN SUPPLY CHAINS VOL. 1

\begin{tabular}{|c|c|c|}
\hline Problem & References & Area of application \\
\hline & & $\begin{array}{l}\text { minimize the total cost of the multiple centres joint distribution } \\
\text { network is proposed. }\end{array}$ \\
\hline \multirow{2}{*}{ 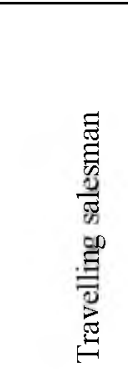 } & Defryn and Sorensen 2018 & $\begin{array}{l}\text { The chapter considers a horizontal logistics cooperation in which } \\
\text { multiple companies jointly solve their logistics optimization problem. } \\
\text { In particular, the case of the multi-objective travelling salesman } \\
\text { problem with a soft time window is considered. }\end{array}$ \\
\hline & Kimms and Kozeletskyi 2016 & $\begin{array}{l}\text { The authors study the cooperative travelling salesman problem (TSP) } \\
\text { with release dates. This problem is modelled as a traditional TSP with } \\
\text { multiple salesmen and depots }\end{array}$ \\
\hline \multirow{3}{*}{ 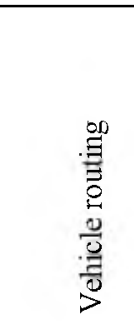 } & Dahl and Derings 2011 & Cooperation in a carrier network \\
\hline & Engevall et al. 2004 & $\begin{array}{l}\text { Distribution-planning situation at the Logistics Department at Norsk } \\
\text { Hydro Olje AB, Stockholm, Sweden. }\end{array}$ \\
\hline & Defryn et al. 2016 & $\begin{array}{l}\text { Consider a selective vehicle routing problem to clarify the } \\
\text { relationship between the behaviour of partners, routing solutions } \\
\text { and cost allocation in horizontal logistics coalitions. }\end{array}$ \\
\hline \multirow[b]{3}{*}{ 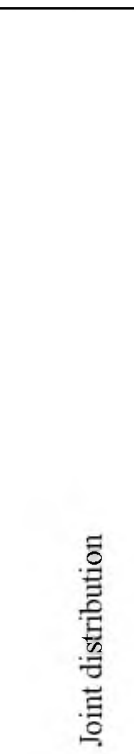 } & Wang et al. 2017 & $\begin{array}{l}\text { An improved Shapley value model based on cooperative game theory } \\
\text { and a cooperative mechanism strategy are presented to obtain the } \\
\text { optimal profit allocation scheme and sequential coalitions } \\
\text { respectively in a two-echelon logistics joint distribution network. }\end{array}$ \\
\hline & Adenso-Diaz et al. 2014 & $\begin{array}{l}\text { Cooperation among firms in the running of logistics operations has } \\
\text { been demonstrated. A model has been proposed for linking together } \\
\text { different transportation requirements, it was obtained after merging } \\
\text { the deliveries of different partner firms. }\end{array}$ \\
\hline & Agarwal and Ergun 2010 & $\begin{array}{l}\text { The chapter addresses the problem of the design of large-scale } \\
\text { transport networks and the allocation of a limited capacity on the } \\
\text { transportation network among the carriers in the alliance. The } \\
\text { concepts derived from mathematical programming and game theory } \\
\text { are utilized in order to guide the carriers in an alliance to pursue an } \\
\text { optimal collaborative strategy. }\end{array}$ \\
\hline \multirow[b]{2}{*}{ 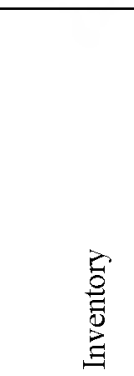 } & Ozener et al. 2013 & $\begin{array}{l}\text { Vendor-management inventory replenishment is considered, the } \\
\text { study was initiated in the context of an industrial gas company. }\end{array}$ \\
\hline & Soysal et al. 2018 & $\begin{array}{l}\text { The chapter develops a decision support model in the inventory } \\
\text { routing problem with multiple suppliers and customers. The results } \\
\text { show that horizontal collaboration among the suppliers contributes to } \\
\text { a decrease in the aggregated total cost and emissions in the logistics } \\
\text { system. }\end{array}$ \\
\hline
\end{tabular}




\subsection{Solution methodology}

In the field of logistics cooperation the challenge is to design a mechanism that will distribute the collaborative profit/costs among the partners. A fair allocation of the benefits of collaboration among the partners is crucial to the stability of any coalition [Guajardo 2018]. The costs/profits allocation problem may be addressed using several methods. One approach is cooperative game theory analysis (CGT), which is usually aimed at answering questions about how the resulting benefits will be shared among the coalition members [Beimborn 2014]. Cooperative games are concerned with the distribution of cooperation benefits when the players cooperate. Most applications of CGT are in the areas of scheduling, cost saving, negotiation and bargaining [Barron 2013]. The most well-known cost allocation methods adapted to the horizontal logistics cooperation problem are the Shapley value [Krajewska et al. 2008, Liu et al. 2010, Wang et al. 2015] and the Nucleolous [Agarwal and Ergun 2010, Frisk et al. 2010, Lozano et al. 2013]. Other methods proposed in the context of logistics cooperation are e.g. proportional methods [Krajewska and Kopfer 2006, Ozener 2014], core centre [Lozano et al. 2013], and marginal methods [Frisk et al. 2010]. Another approach is to use a mathematical programming tool to compute the potential savings of collaboration [Lozano et al. 2013]. Another commonly used technique concerning the operational aspects of horizontal logistics cooperation is the auction-based mechanism [Dai and Chen 2011, Wang and Kopfer 2011].

\subsection{Benefits of collaboration}

The benefits of collaborative transportation were identified in the literature quite some time ago [Samet et al. 1984]. The current state-of-the-art models indicate that the firms that choose to collaborate may benefit in several ways including cost savings [Lozano et al. 2013], reduced $\mathrm{CO}_{2}$ emissions [Ballot and Fontane 2010], innovation Borman and Janssen 2012], and an increase in quality [Ulbrich 2010]. The optimal way to obtain the benefits of collaboration are the use of the backhaul-based [Juan et al. 2014] and line exchange mechanism [Ozener et al. 2011, Wang and Kopfer, 2014] to evaluate the relevance of the method used in saving routing and environmental costs. In the first method, companies share trucks and routes in order to improve their individual turnovers. In the lane-exchange method, the optimal set of cycles covering the contract lanes are assigned to the relevant collaborative firms. The number of journeys of empty vehicles is reduced and, the resulting profits are redistributed between the partners. The collaboration usually renders significant benefits, ranging from $8.6 \%$ to $46 \%$ cost 
savings (see Table 3.), and 11-54\% emission reductions in road freight transportation (see Table 4.).

Table 3. Real-data cases in horizontal logistics cooperation.

\begin{tabular}{|c|c|c|c|c|}
\hline References & Article type & Solution approach & Cost savings & Sector \\
\hline Dahl and Derings & Simulation study & $\begin{array}{ll}\text { Collaborative } & \text { Decision }\end{array}$ & $13.85 \%$ & \\
\hline 2011 & & $\begin{array}{l}\text { Support System in an express } \\
\text { carrier network }\end{array}$ & & \\
\hline Flisberg et al. 2015 & Empirical study & Linear programming & $22 \%$ & Forest fuel transport \\
\hline Engevall et al. 2004 & Case study analysis & Game theory & $46 \%$ & $\begin{array}{l}\text { Logistics Department } \\
\text { in Sweden }\end{array}$ \\
\hline $\begin{array}{ll}\text { Guajardo } & \text { and } \\
\text { Ronnqvist 2015 } & \end{array}$ & Case study analysis & Linear programming & $\begin{array}{ll}8.6 \%, & 9.3 \% \\
14.2 \% & \end{array}$ & Forest transportation \\
\hline $\begin{array}{l}\text { Massol and Tchung- } \\
\text { Ming } 2010\end{array}$ & Experiment & Game theory & $\begin{array}{l}10.5 \%, 11.9 \% \\
12.9 \%\end{array}$ & Gas industry \\
\hline
\end{tabular}

Table 4. Emissions reduction in horizontal logistics cooperation.

\begin{tabular}{llll}
\hline \multicolumn{1}{c}{ References } & \multicolumn{1}{c}{ Solution approach } & $\mathrm{CO}_{2}$ reduction & Sector \\
\hline Frisk et al. 2010 & $\begin{array}{l}\text { Game theory }- \text { Shapley } \\
\text { value and Nucleolus }\end{array}$ & Forest companies in Sweden \\
\hline Xu et al. 2012 & $\begin{array}{l}\text { Game theory }- \text { Shapley } \\
\text { value }\end{array}$ & 0.41 tonnes/week & $\begin{array}{l}\text { The retail logistics network } \\
\text { in France }\end{array}$ \\
\hline Pan et al. 2013 & Mixed integer linear & $11-18 \%$ & Carrier company in France \\
& programming & & \\
\hline Jacobs et al. 2014 & Game theory - Shapley & $38-54 \%$ & Manufacturing in Belgium - \\
& value & & fresh and chilled products \\
\hline Zhu et al. 2016 & Analysis of variance & $41 \%$ & Logistics provider serving \\
& & & companies in Sweden and \\
& & & Norway \\
\hline
\end{tabular}

\section{CONCLUDING REMARKS}

In summary, this article presents the results of 43 analyses of articles using practical examples of horizontal collaboration in logistics described in the literature. On the basis of the conducted analyses, all of the research questions posed in the introduction were answered. The problems solved by horizontal cooperation in logistics are as follows: transportation planning, travelling salesman, vehicle routing, joint distribution, inventory related problems. The solution methodologies adopted are as follows: cooperative game theory analysis, proportional methods, core centre, marginal, mathematical programming, auction-based mechanism. The main benefits of horizontal cooperation in the analysed articles are as follows: cost reduction, $\mathrm{CO}_{2}$ 
reduction, improved quality of customer service, innovation, reduced supply risk. Case study articles concerning horizontal cooperation in logistics are most frequently published in logistics and supply chain management journals.

Through an analysis of the time of publication of individual articles, the growing trend of interest in the issue of $\mathrm{CO}_{2}$ emission reduction in logistics may be observed. In the opinion of the authors of this article, this issue will become ever more important in the upcoming articles concerning the motivating factors and benefits of horizontal collaboration in logistics.

\section{ACKNOWLEDGEMENTS}

The work was supported by National Science Center Poland under grant no. 2018/02/X/HS4/02777.

\section{REFERENCES}

Adenso-Díaz, B., Lozano, S., Garcia-Carbajal, S., \& Smith-Miles, K. (2014). Assessing partnership savings in horizontal cooperation by planning linked deliveries. Transportation Research Part A: Policy and Practice, 66, 268-279. DOI: 10.1016/j.tra.2014.05.013

Agarwal, R., \& Ergun, Ö. (2010). Network design and allocation mechanisms for carrier alliances in liner shipping. Operations research, 58(6), 1726-1742. DOI: 10.1287/opre. 1100.0848

Akkerman R., Farahani P., Grunow M., 2010, Quality, safety and sustainability in food distribution: a review of quantitative operations management approaches and challenges, OR Spectrum 32, 863-904. DOI: 10.1007/s00291-010-0223-2.

Ballot, E., \& Fontane, F. (2010). Reducing transportation CO2 emissions through pooling of supply networks: perspectives from a case study in French retail chains. Production Planning \& Control, 21(6), 640-650. DOI: 10.1080/09537287.2010.489276

Barron, E. N. (2013). Game theory: an introduction (Vol. 2). John Wiley \& Sons.

Beimborn, D. (2014). The stability of cooperative sourcing coalitions-game theoretical analysis and experiment. Electronic Markets, 24(1), 19-36. DOI: 10.1007/s12525-013-0128-4

Borman, M., \& Janssen, M. (2008). The Design and Success of Shared Services Centres. ECIS 2008 Proceedings. 77. https://aisel.aisnet.org/ecis2008/77 (pp. 2209-2220).

Cruijssen, F. C. A. M. (2006). Horizontal cooperation in transport and logistics. Tilburg: CentER, Center for Economic Research. 
Cruijssen, F., Cools, M., \& Dullaert, W. (2007). Horizontal cooperation in logistics: opportunities and impediments. Transportation Research Part E: Logistics and Transportation Review, 43(2), 129-142. DOI: 10.1016/j.tre.2005.09.007

Dahl, S., \& Derigs, U. (2011). Cooperative planning in express carrier networks - An empirical study on the effectiveness of a real-time Decision Support System. Decision Support Systems, 51(3), 620-626. DOI: 10.1016/j.dss.2011.02.018

Dai, B., \& Chen, H. (2011). A multi-agent and auction-based framework and approach for carrier collaboration. Logistics Research, 3(2-3), 101-120. DOI: 10.1007/s12159-0110046-9

Defryn, C., Sörensen, K., \& Cornelissens, T. (2016). The selective vehicle routing problem in a collaborative environment. European Journal of Operational Research, 250(2), 400-411. DOI: $10.1016 /$ j ejor.2015.09.059

Doukidis, G. I., Mason, R., Lalwani, C., \& Boughton, R. (2007). Combining vertical and horizontal collaboration for transport optimisation. Supply Chain Management: an international journal. DOI: 10.1108/13598540710742509

Engevall, S., Göthe-Lundgren, M., \& Värbrand, P. (2004). The heterogeneous vehicle-routing game. Transportation Science, 38(1), 71-85. DOI: 10.1287/trsc.1030.0035

European Commission. (2001). Guidelines on the Applicability of Article 81 of the EC Treaty to Horizontal Cooperation Agreements. Official Journal of the European Communities, $100,2-30$.

Flisberg, P., Frisk, M., Rönnqvist, M., \& Guajardo, M. (2015). Potential savings and cost allocations for forest fuel transportation in Sweden: A country-wide study. Energy, 85, 353-365. DOI: 10.1016/j.energy.2015.03.105

Frisk, M., Göthe-Lundgren, M., Jörnsten, K., \& Rönnqvist, M. (2010). Cost allocation in collaborative forest transportation. European Journal of Operational Research, 205(2), 448-458. DOI: 10.1016/j.ejor.2010.01.015

Gansterer, M., \& Hartl, R. F. (2018). Collaborative vehicle routing: a survey. European Journal of Operational Research, 268(1), 1-12. DOI: 10.1016/j.ejor.2017.10.023

Guajardo, M., \& Rönnqvist, M. (2015). Operations research models for coalition structure in collaborative logistics. European Journal of Operational Research, 240(1), 147-159. DOI: 10.1016/j.ejor.2014.06.015 
Guajardo, M. (2018). Environmental benefits of collaboration and allocation of emissions in road freight transportation. In Sustainable Freight Transport (pp. 79-98). Springer, Cham. DOI: $10.1007 / 978-3-319-62917-9+6$

Jacobs, K., Van Lent, C., Verstrepen, S., \& Bogen, M. (2014). Horizontal Collaboration in Fresh \& Chilled Retail Distribution. $\mathrm{CO}^{3}$ test case report. http://www.co3project.eu/wo3/wp-content/uploads/2011/12/CO3-Deliverable-Nestlé-Pepsico-STEFcase-study-1.pdf

Jemai, Z., Rekik, Y., \& Kalaï, R. (2013). Inventory routing problems in a context of vendormanaged inventory system with consignment stock and transshipment. Production Planning \& Control, 24(8-9), 671-683. DOI: 10.1080/09537287.2012.666844

Juan, A. A., Faulin, J., Pérez-Bernabeu, E., \& Jozefowiez, N. (2014). Horizontal cooperation in vehicle routing problems with backhauling and environmental criteria. Procedia-Social and Behavioral Sciences, 111, 1133-1141. DOI: 10.1016/j.sbspro.2014.01.148

Kimms, A., \& Kozeletskyi, I. (2016). Core-based cost allocation in the cooperative traveling salesman problem. European Journal of Operational Research, 248(3), 910-916. DOI: 10.1016/j.ejor.2015.08.002

Krajewska, M. A., \& Kopfer, H. (2006). Collaborating freight forwarding enterprises. OR spectrum, 28(3), 301-317. DOI: 10.1007/s00291-005-0031-2

Krajewska, M. A., Kopfer, H., Laporte, G., Ropke, S., \& Zaccour, G. (2008). Horizontal cooperation among freight carriers: request allocation and profit sharing. Journal of the Operational Research Society, 59(11), 1483-1491. DOI: 10.1057/palgrave.jors.2602489

Lehoux, N., Audy, J. F., Sophie, D. A., \& Rönnqvist, M. (2009, October). Issues and experiences in logistics collaboration. In Working Conference on Virtual Enterprises (pp. 69-76). Springer, Berlin, Heidelberg. DOI: 10.1007/978-3-642-04568-4_8

Leitner, R., Meizer, F., Prochazka, M., \& Sihn, W. (2011). Structural concepts for horizontal cooperation to increase efficiency in logistics. CIRP Journal of Manufacturing Science and Technology, 4(3), 332-337. DOI: 10.1016/j.cirpj.2011.01.009

Liu, P., Wu, Y., \& Xu, N. (2010). Allocating collaborative profit in less-than-truckload carrier alliance. Journal of Service science and Management, 3(01), $143 . \quad$ DOI: $10.4236 /$ jssm. 2010.31018 
Lozano, S., Moreno, P., Adenso-Díaz, B., \& Algaba, E. (2013). Cooperative game theory approach to allocating benefits of horizontal cooperation. European Journal of Operational Research, 229(2), 444-452. DOI: 10.1016/j.ejor.2013.02.034

Massol, O., \& Tchung-Ming, S. (2010). Cooperation among liquefied natural gas suppliers: Is rationalization the sole objective?.Energy Economics, 32(4), 933-947. DOI: $10.1016 /$ j.eneco.2010.02.008

Özener, O. Ö. (2014). Developing a collaborative planning framework for sustainable transportation. Mathematical Problems in Engineering, 2014. DOI: 10.1155/2014/107102

Özener, O. Ö., Ergun, Ö., \& Savelsbergh, M. (2011). Lane-exchange mechanisms for truckload carrier collaboration. Transportation Science, 45(1), 1-17. DOI: 10.1287/trsc.1100.0327

Pan, S., Ballot, E., \& Fontane, F. (2013). The reduction of greenhouse gas emissions from freight transport by pooling supply chains. International Journal of Production Economics, 143(1), 86-94. DOI: 10.1016/j.ijpe.2010.10.023

Samet, D., Tauman, Y., \& Zang, I. (1984). An application of the Aumann-Shapley prices for cost allocation in transportation problems. Mathematics of Operations Research, 9(1), 2542. DOI: $10.1287 /$ moor.9.1.25

Soysal, M., Bloemhof-Ruwaard, J. M., Haijema, R., \& van der Vorst, J. G. (2018). Modeling a green inventory routing problem for perishable products with horizontal collaboration. Computers \& Operations Research, 89, 168-182. DOI: $10.1016 /$ j .cor. 2016.02 .003

Ulbrich, F. (2006). Improving shared service implementation: adopting lessons from the BPR movement. Business Process Management Journal, 12(2), 191-205. DOI: $10.1108 / 14637150610657530$

Wang, X., \& Kopfer, H. (2011). Collaborative transportation planning of less-than-truckload freight: request exchange through a route-based combinatorial auction. Bremen: Faculty, 7 , 189-198. DOI: $10.1007 / \mathrm{s} 00291-013-0331-\mathrm{x}$

Wang, Y., Ma, X., Xu, M., Wang, L., Wang, Y., \& Liu, Y. (2015). A methodology to exploit profit allocation in logistics joint distribution network optimization. Mathematical Problems in Engineering, 2015. DOI: 10.1155/2015/827021

Wang, X., \& Kopfer, H. (2014). Collaborative transportation planning of less-than-truckload freight. OR spectrum, 36(2), 357-380. DOI: 10.1007/s00291-013-0331-x 
Xu, X., Pan, S., \& Ballot, E. (2012). Allocation of transportation cost \& co2 emission in pooled supply chains using cooperative game theory. IFAC Proceedings Volumes, 45(6), 547-553. DOI: $10.3182 / 20120523-3-R O-2023.00078$

Zhu, W., Nowak, M. P., \& Erikstad, S. O. (2016). Emission allocation issues in repositioning transportation. International Journal of Sustainable Transportation, 10(4), 365-375. DOI: $10.1080 / 15568318.2014 .960114$

A. Kolinski et al. (eds.), Contemporary challenges in supply chains, Vol. 1, https://doi.org/10.17270/B.M.978-83-66017-88-7.1 